\title{
Irony, Disruption and Moral Imperfection
}

\section{Dieter Declercq $^{1}$}

Accepted: 10 July 2020 / Published online: 20 July 2020

(C) The Author(s) 2020

\begin{abstract}
Irony has a suspicious moral reputation, especially in popular media and internet culture. Jonathan Lear (2011) introduces a proposal which challenges this suspicion and identifies irony as a means to achieve human excellence. For Lear, irony is a disruptive uncanniness which arises from a gap between aspiration and actualisation in our practical identity. According to Lear, such a disruptive experience of ironic uncanniness reorients us toward excellence, because it passionately propels us to really live up to that practical identity. However, Lear's understanding of irony is idiosyncratic and his proposal overlooks that disruption often results from value incompatibility between different practical identities. The disruption which follows from value incompatibility does not inherently reorient us toward excellence. The point is exactly that achieving excellence in one practical identity is sometimes incompatible with excellence in the other. Pace Lear, I do not identify this disruptive experience as a central example of irony. Instead, I consider irony a virtuous coping strategy for such disruption, because it introduces the necessary distance from our moral imperfection to sustain practical deliberation and maintain good mental health. Such virtuous irony negotiates a golden mean between too little disruption (complete insensitivity toward one's imperfection) and too much disruption (a complete breakdown of practical deliberation and mental health). I argue that ironic media in popular culture provide a rich source of such virtuous irony, which I demonstrate through analysis of satirical examples.
\end{abstract}

Keywords Jonathan Lear · Value incompatibility · Moral perfectionism · Disruption · Irony · Echo vs. pretence

\section{Introduction}

The moral status of irony is suspicious. Philosophers (e.g. Blackburn 1998; Kierkegaard 1989 [1841]) and cultural critics (e.g. Rosenblatt 2001; Wampole 2012, 2016) often decry irony as

Dieter Declercq

dd324@kent.ac.uk

1 School of Arts, Jarman Building, University of Kent, Canterbury CT27UG, UK 
spineless whimsy. The usual suspicion is that irony equals detachment from moral responsibility and earnestness. In defiance of these suspicions, Jonathan Lear (2011) boldly proposes that we should cultivate irony to achieve human excellence. For Lear, irony is an uncanny disruption of our practical identity which does not disorient us, but rather directs us toward virtue.

Lear's proposal is a welcome reassessment of irony's morally suspicious reputation, while 'disruption' is a particularly fruitful concept to frame irony's potential for virtue. Hence, Lear's account offers seminal avenues for a moral reinvestigation of irony, unavailable in other philosophical accounts (e.g. Nehamas 1998). However, I will argue that what Lear calls "anxious, uncanny longing" $(2011,117)$ is only irony in a peripheral sense, and, because his proposal differs radically from other accounts, it fails to alleviate common moral suspicions (see Bernstein 2016, 37).

Lear's account is problematic because he insists that existentially relevant irony is radically different from irony as a figure of speech, i.e. 'communicative irony' (Lear 2001, 5; passim). This oversight is especially problematic because communicative irony is what most people routinely conceive irony to be. At the same time, Lear's understanding of communicative irony as "saying the opposite of what one means" $(2011,6)$-although classical and seminal (see Vlastos 1991) - is outdated, and has long been rejected by philosophers working in aesthetics (Currie 2006, 2011) and at the interface of philosophy and linguistics (Sperber and Wilson 2012).

Lear's account is indicative of how philosophers are often at cross-purposes when investigating irony, which is why there still much confusion and misunderstanding about the topic (see Bernstein 2016, 1). In this article, I argue that the morally suspicious reputation of irony unduly persists because the irony which is existentially and morally relevant has not been primarily understood as an offshoot of communicative irony. Redressing this oversight, I do not conclude that irony is by default morally virtuous. Yet, equally, irony is also not by default morally suspicious. Rather, irony is a form of emotional distancing which can mediate the unavoidable disruption of moral imperfection in our lives, when applied with the right measure, in the right circumstances.

This article has four more sections. In section 2, I develop an overview of Lear's account of irony as uncanny disruption. Section 3 critiques the idiosyncrasy of Lear's account by providing an overview of different kinds of irony and introducing a new form of complex communicative irony, which I call 'ironic characters'. In section 4, I ague that ironic characters can mitigate the disruption of moral imperfection. I challenge Lear's proposal that disruption inherently reorients us toward excellence. Instead, I introduce value incompatibility as an unavoidable disruption in our moral lives, which risks breaking down practical deliberation and compromise mental wellbeing. Section 5 concludes by framing the urgency of disruptive value incompatibility in the context of globalized information technology.

\section{Lear on Irony}

For Lear, irony is an experience of disruption in our practical identity which reorients us toward human excellence. Lear provides the example of 'teacher' as a practical identity, which introduces norms that guide practical deliberation (2011, 4/11). Consider a university lecturer who has fifty undergraduate essays to mark but resists the temptation of reducing work by providing only superficial feedback, because that is not what a 'teacher' would do. According 
to Lear, human excellence requires that "we inhabit a practical identity well" $(2011,4)$. It does not follow that we always know how to act in accordance with our practical identity. Instead, Lear argues that achieving human excellence involves "disruption and disorientation" (2011, 14). In my example, the lecturer would be disrupted and disoriented if they were clueless about what marking fifty essays has to do with 'teaching' and, equally, what it even means to be a 'teacher'.

Such disruption is ironic when it "manifests an inchoate intimation that there is something valuable about teaching" (Lear 2011, 19). In other words, the lecturer may not know what 'teaching' is, only that activities commonly associated with being a 'teacher' (like marking) fall woefully short of the ideal; yet, they do intuit that such a valuable ideal exists. Therefore, Lear calls ironic disruption an "experience of would-be-directed uncanniness" (2011, 19, original emphasis). In such an uncanny experience, everything that was once familiar about 'teaching' has now become unfamiliar, but there is nonetheless an embryonic desire toward excellence. Therefore, Lear identifies irony as "erotic uncanniness" (2011, 117, original emphasis).

According to Lear, "[i]t is constitutive of human excellence that one develop a capacity for appropriately disrupting one's understanding of what such excellence consists in" (2011, 37). For example, to achieve excellence as a 'teacher', the lecturer must harness the force of ironic disruption to transcend received social understandings of teaching and tap into an otherwise inaccessible direction toward human excellence (Lear 2011, 25). Although human excellence does not involve experiencing such disruption all the time, we should cultivate "practical wisdom about when it is appropriate to deploy irony" (Lear 2011, 30).

Lear's account introduces a sense of existential disruption that is undoubtedly familiar. Just think of academics who are at a loss about what it means to be a 'teacher' in a market environment where students are consumers. The lecturer from my example may find themselves at loose ends because they are unsure what 'keeping the customer satisfied' has to do with being a 'teacher' - but, equally, they do not know how else to be a 'teacher' given the marketization of higher education. Although this experience is unsettling, Richard Bernstein rightfully notes that there is something valuable about "an uncanny experience that provokes a search for new direction" $(2016,45)$. In this respect, Lear frames his account as an "attempt to use the force of disruption in a creative, poetic manner, instead of suffering from it or being confused by it" (Sholl 2011, 9, my translation).

However, it is not entirely clear exactly how irony succeeds to overcome the mental suffering or confusion of disruption. Lear acknowledges that "getting the hang of it does not come that easily", so irony is hardly a strategy that is readily available in practical deliberation $(2011,31)$. Moreover, the nature and force of Lear's irony is equally difficult to comprehend without actually experiencing it. Although this gnomic quality is integral to irony on Lear's account, it means that only the initiated can grasp how irony directs us toward human excellence. In section 4, I further argue that Lear's account overlooks that achieving the ideal of excellence is often not possible, as in the case of being a 'teacher' in a market environment, which often involves compromising between ideal and reality. In those cases, irony is useful not because it directs us to human excellence, but because it helps us deal with the disruption of moral imperfection.

First, I move onto disputing that Lear's uncanny disruption is really (a central form of) irony. Therefore, Lear's account fails to rebut common moral suspicions about irony in philosophy and cultural criticism. Lear identifies the "contemporary cultural reception of irony" as a "defense against getting rattled by one's own commitments" $(2011,119)$. He 
specifically refers to the "ataraxia" on offer in Richard Rorty's defence of the liberal ironist (Lear 2011, 119). For Rorty (1989), an ironist is someone who knows that their central values have been shaped by contingency (e.g. as opposed to my friend, I happened to grow up in a Catholic family, but the situation could easily have been reversed). Aware of such unavoidable contingency, the ironist is "never quite able to take themselves seriously" (Rorty 1989, 73-74).

Irony's professed lack of commitment to values is morally suspicious. Simon Blackburn dismisses Rotry's ironist as a "weightless aesthete, to whom all real commitment is a subject of joke or parody" and argues that if we are serious about ethics, "we can safely set the irony aside" (1998, 290). The early Kierkegaard is similarly suspicious of irony, which he (following Hegel) defines as infinite absolute negativity (1989 [1841]). John Lippitt $(2000,149)$ links Kierkegaard's infinite absolute negativity to Wayne Booth's concept of "unstable irony" $(1974,240)$, a nihilistic attitude which refuses to affirm anything. Kierkegaard discerns this attitude in Socrates, whom he therefore dismissed "as a self-centred and politically apathetic figure" (Söderquist 2007, 82), rejecting "earnestness about anything” (Frazier 2006, 114).

The moral suspicion that irony equals political apathy also permeates cultural criticism. Roger Rosenblatt famously hoped that the "horror" of 9/11 "could spell the end of the age of irony" (2001). According to Rosenblatt, the American public sphere was characterised by "detachment and personal whimsy", which meant that "even the most serious things were not to be taken seriously" (2001). Yet, a decade later, Christy Wampole still decried that "irony is the ethos of our age" (2012). For Wampole, irony is a "self-defensive mode" of "dissimulation" through which hipsters and other white middle-class Millennials "dodge responsibility for [their] choices" (2012). Especially after the election of Donald Trump, Wampole strongly urged to abandon irony in favour of sincerity and seriousness (2016). Her plea shares the aspirations for a new sincerity or post-ironic society first advanced by David Foster Wallace (1993).

Cultural critics and philosophers often associate irony with morally undesirable qualities, including apathy, cynicism, detachment, dissimulation, nihilism, and whimsy. They similarly dissociate irony from morally desirable qualities like earnestness, commitment, responsibility, and seriousness. In defiance of these suspicions, Lear argues that cultivating a capacity for irony is really "an expression of earnestness and commitment" (2011, 38). He therefore dismisses the usual moral suspicions about irony as misplaced concerns about "a derivative form" $(2011,9)$. According to Lear, "[w]e tend to think casually of "the ironist" as someone who is able to make certain forms of witty remarks, perhaps saying the opposite of what he means, of remaining detached by undercutting any manifestation of seriousness" $(2011,9)$. Following the later Kierkegaard (and his pseudonyms), Lear dismisses this routine understanding by claiming that "[i]rony is an existence-determination, so nothing is more ridiculous than to suppose it to be a figure of speech" (Johannes Climacus, cited in Lear 2011, XIII).

Revisiting the example of a teacher who deploys their capacity for ironic disruption, Lear acknowledges that they may appear detached, because they radically doubt that received ideas about teaching (such as marking essays) contribute to being a 'teacher' $(2011,19)$. Yet, Lear urges that irony really involves "detachment" from the received social understandings of a practical identity "to facilitate attachment to the more robust version of the ideal" $(2011,38)$. For Lear, the routine understanding of irony is a weak derivative of the genuine article because it is "deaf to the uncanny disruptions of would-be directedness" $(2011,38)$. However, because Lear's account differs so radically from routine understandings of irony, it is unclear that he has really attenuated common suspicions. Sceptics (including myself) may worry that Lear identifies an altogether different, much rarer phenomenon than irony. 


\section{What Is Irony?}

'Irony' can refer to multiple phenomena, which is why philosophers and critics risk equivocating on its meaning or unduly stretch its extension. Concretely, Bernstein worries that Lear's departure from routine understandings of irony is "so radical that he opens himself up to the charge that he is simply changing the subject" - especially because "for Lear, irony has (essentially) nothing to do with language" (2016, 37-38). To establish greater clarity, I outline four main types of irony: situational irony (an experience), the irony relevant to moral evaluation (an attitude), communicative irony (a rhetorical trope) and dramatic irony (a narrative technique). I identify Lear's ironic disruption as a peripheral form of situational irony which is unrelated to the phenomenon that commonly invites moral suspicion. I also attenuate those common moral suspicions by introducing an alternative account, which frames existentially relevant irony as an offshoot of communicative irony.

Situational irony "requires a contrast between a norm or expectation or ambition on the one hand and reality on the other" (Currie 2011, 164). This contrast is hard to define but involves an experience of the universe frustrating human affairs in a seemingly planned and perversely perfect way. For example, there is no inherent irony about receiving unemployment benefits, but it is ironic when exactly that person who has always fulminated against benefits now depends on them for their livelihood. Another classic example of situational irony is a person who worked hard all their life, only to die the day before retiring. Lear's experience of uncanny disruption can be charitably framed as a peripheral kind of situational irony.

For Lear, irony involves the experience of a "gap" between the received understanding and implied ideal of a practical identity (2011, 11). Such a gap arguably involves the perversely perfect contrast that characterises situational irony. For example, the marketization of higher education may feel deeply ironic to a university lecturer for whom being a 'teacher' always seemed to involve critical thinking about society, including capitalism. Nevertheless, erotic uncanniness, the defining feature of Lear's irony, is unrelated to situational irony. A grieving child, who ponders their father's death on the day of his pension, may well think it is ironic but does not experience "an inchoate intimation" of human excellence $(2011,11)$.

Hence, Lear's uncanny disruption is differentiated by a characteristic which is not a standard feature of irony. Therefore, uncanny disruption is at best a special kind of situational irony. Moreover, historically, the routine understanding of situational irony is not derived from ironic disruption, because erotic uncanniness is not part of irony's etymology (see Bernstein 2016 , 2). Still, Lear may argue that routine understandings of irony are "diminished" because less profound than uncanny disruption $(2011,38)$. This is a plausible argument. Yet, it does not change the fact that Lear's erotic uncanniness is a peripheral form of irony, defined by characteristics which only he considers central to irony. Although this concession does not problematize the content of Lear's account (for such a challenge, see section 4), it does mean his proposal does not resolve common suspicions about irony.

Pace Lear, when philosophers and cultural critics worry about irony, they do not worry about an experience (of a contrast between ideal and reality), but about an attitude (of detachment). Yet, like Lear, they rarely address what exactly makes this attitude ironic. To redress this problem, I propose that for some attitude to be ironic, it must share an attitudinal quality with communicative irony. This link has been overlooked, mostly because philosophers and cultural critics who are interested in the moral and existential dimensions of irony have typically not engaged with debates about communicative irony. Hence, philosophers like 
Lear tend to have an obsolete understanding of communicative irony as "saying the opposite of what one means" $(2011,6)$.

However, there is now a consensus that "what irony conveys is not a figurative meaning but an attitude", specifically dissociation from an unreasonable perspective (Sperber and Wilson 2012, 141; see also Currie 2006, 112-113). Irony can be jovial, playful, biting, or caustic (see Hutcheon 1985, 45), but it always involves dissociation from a thought attributed to a certain target. Ironic communication is a kind of stancetaking, whereby language users express a dissociative stance in relation to a proposition (see Burgers et al. 2011, 305). Therefore, I propose that for an attitude to be called 'irony', it must involve such dissociative stancetaking.

There are currently two main rival theories of communicative irony, the echoic theory (Sperber and Wilson 2012) and the pretence theory (Currie 2011). Both theories agree that communicative irony is essentially the expression of a dissociative attitude toward a perspective but disagree about the mechanics behind this process. Suppose I mock a colleague's suggestion by ironically saying "That's a great idea!" According to the echoic theory of irony, I do not communicate that thought as my own, but instead tacitly attribute it to my colleague, in order to tacitly dissociate myself from it (by implying that I find the idea ridiculous). By contrast, on the pretence theory, I do not engage in a sincere speech act, but only pretend to assert this defective viewpoint, to ridicule my colleague who genuinely occupies a similar perspective. In both cases, ironic communication is implicit, and my colleague is left to infer my dissociative attitude.

Of the two rival theories, the pretence theory seems particularly suited to clarify what makes certain morally suspicious attitudes ironic. As discussed, cultural critics and philosophers often associate irony with a detached and whimsical attitude devoid of sincerity, and pretence is often associated with insincerity. Bernard Williams argues that "a sincere assertion will be one made by someone who himself believes that P" while "an insincere assertor (...) pretends to express his belief" $(2002,57)$. Williams highlights that this characterisation also applies to ironic communication $(2002,57)$. These connections reveal a conceptual kinship, if not confusion, between irony, pretence, and insincerity, which also characterises debates about morally suspicious irony. This confusion needs to be untangled to bring greater clarity to the moral evaluation of irony.

First, even if irony really involves pretence, not all morally suspicious pretence is ironic. Consider ironically liking a music genre, which would involve pretending to like that genre, as a targeted act of dissociation from those that genuinely do like it. Hence, ironically liking a genre of music is not the same as inauthentically indulging in unsophisticated music choices (by pretending not to really enjoy them). In this respect, the Dutch and Flemish radio station QMusic regularly hosts Foute Parties, where people enjoy music genres that would otherwise be considered a faux pas (i.e. 'fout'). Such behaviour is not strictly speaking ironic, because it is not in the first place targeted at people who genuinely like that music (see Currie 2006, $116 \mathrm{ff}$ ). Instead, it is an insincere form of aesthetic appreciation, which permits people to indulge in music genres they cannot sincerely like, for fear of social marginalization.

The same goes for indulging in other taboo tastes, like racist humour. For example, 'hipster racism' is typically decried as kind of irony indulged in by "white, often progressive people who think they are hip to racism, which they mistakenly believe gives them permission to say and do racist things without actually being racist" (Rachel Dubrofsky in Mahdawi 2017). Imagine someone who knows why dressing up in blackface for a party is wrong, but does it anyway, because they profess that their knowingness excuses their behaviour as simply 'joking around'. When criticized, they might defend their actions by claiming that they were just 
'being ironic'. Such behaviour is certainly morally problematic, but to be ironic, it must involve more than just a flippant and knowing attitude about racism. Instead, real irony would be targeted at people who are serious about racism - which is still morally problematic, but at least involves genuinely taking a stand on a political issue.

A related case is a specific kind of online trolling which disavows its actual intent. It is a strategy among the alt-right to distribute racist memes under the motto of provoking backlash from progressive critics, who are ridiculed for failing to see that the content was 'ironic'. Nevertheless, these memes are genuinely racist, and the professed dissimulation serves to create a greater tolerance for alt-right ideologies by making it acceptable to endorse them 'ironically' (Marwick and Lewis 2015, 1). Such activity may also cause so-called "irony poisoning", as in the case of a German man who ended up trying to burn down the house of a refugee after 'ironically' exchanging racist memes (Fisher and Taub 2018). Such attitudes are certainly dangerous but not ironic simply because they involve communication which professes not to endorse its literal message or conceals its actual intent. If such attitudes are sometimes ironic, it only when they involve an active dissociation from those who find such content repellent (like progressives who do not find racism funny).

Hence, some attitudes which are morally suspicious because insincere are sometimes too quickly or even mistakenly labelled as ironic. Such conflation unduly fuels moral suspicion about irony. Perhaps the association with pretence facilitates such undue extension or makes irony appear more insincere than it really is. Still, although the rival echoic theory outlines an understanding of irony that is divorced from pretence, it is not altogether incompatible with inauthenticity. Somebody who constantly echoes defective tastes and behaviours tacitly attributed to somebody else, without affirming their own values, certainly does not live an authentic life. Worries that too much irony is morally problematic are therefore justified. Nevertheless, if ironic attitudes are reframed as an offshoot of communicative irony, it should be clear they are not by default morally suspicious.

In fact, irony can and has been put to philosophical use. Consider Voltaire's Candide, the great Enlightenment satire of Leibnizian optimism. Candide cultivates a complex irony which I call 'ironic characters'. Ironic characters are a ploy in the ironic communication of authors by asserting viewpoints in a fictional world which audiences are cued to understand as similar to deficient viewpoints held by real people. They typically serve a satirical function in an author's critique of some unreasonable perspective. Most importantly, they can be virtuously integrated into a legitimate philosophical project, as Voltaire demonstrates in his philosophical critique of Leibniz.

One ironic character, which Voltaire introduces, is Professor Pangloss, who purports that "things cannot be otherwise than as they are; for all being created for an end, all is necessarily for the best end" (1918 [1759], 2). Pangloss supports this argument with questionable observations like "the nose has been formed to bear spectacles - thus we have spectacles" and "[1] egs are visibly designed for stockings — and we have stockings" (Voltaire 1918 [1759], 2-3). Although it remains implicit in Candide, Pangloss is clearly a stand-in for Leibniz and his optimism that God has created the best of all possible worlds. Using ironic characters like Pangloss, Voltaire dissociates himself from what he considers Leibniz's absurd optimism. Below, I argue that such dissociative stancetaking through ironic characters can be virtuously used to mediate disruption in our moral lives. To understand why, we first need to inspect more closely how ironic characters function as irony.

Ironic characters are similar to, but ultimately different from, another main type of irony, i.e. dramatic irony. According to Gregory Currie, dramatic irony involves the fictional 
representation of situational irony $(2006,127-128)$. It is a narrative technique through which audiences are given access to salient information lacked by some character in a fiction, who, as a result of lacking that information, acts in a way that undermines their aspirations in a perversely perfect manner. A canonical example of dramatic irony is Oedipus's search (in Oedipus Rex) for the murderer of King Laius, which the audience knows is himself. Dramatic irony is also often exploited for comic purposes, as in Shakespeare's Much Ado About Nothing, in which the audience has an overview of how the various characters aim to deceive each other, which they themselves lack.

Similarly, while Pangloss is unaware of the deficiency of his beliefs, the audience are in the know. Yet, while characters who are victim to dramatic irony are the sole butt of the joke (in the fiction), ironic characters like Pangloss tacitly put audiences in mind of real-life targets from whom the author tacitly dissociates themselves. In Oedipus Rex, the only victim of irony is Oedipus himself, while the real target of Voltaire's irony is ultimately not Pangloss, but Leibniz. Hence, ironic characters showcase the tacit attribution and dissociation essential to communicative irony, which characters oblivious to dramatic irony lack. Moreover, audiences are supposed to get that Pangloss is intentionally designed by Voltaire to express thoughts which contrast with their own thoughts about real affairs. By contrast, for dramatic irony, audiences only need to grasp a contrast between their knowledge about the fictional world and the internal perspectives of characters.

For these reasons, unlike dramatic irony, ironic characters are a proper extension of communicative irony, because they serve as ploys in the ironic communication of their authors. Crucially, the narrative structure of ironic characters is incompatible with the kind of pretence stipulated by the pretence theory, which is why the echoic theory ultimately affords a better understanding of communicative irony. On the pretence theory, "the pretence that is fundamental to irony is not a pretence of doing; it's a pretence of being. In pretending to assert or whatever, one pretends to be a certain kind of person - a person with a restricted or otherwise defective view of the world or some part of it" (Currie 2006, 116). The idea is that "the most efficient way for an ironic speaker to criticize the foolishness of people is not only to pretend to behave in a foolish manner but to pretend to be a foolish person" (Popa-Wyatt 2014, 138, original emphasis).

This kind of pretence of being is not compatible with what Voltaire is doing in Candide. Consider again Pangloss, who argues that "[p]igs were made to be eaten - therefore we eat pork all the year round. Consequently, they who assert that all is well have said a foolish thing, they should have said all is for the best" (Voltaire 1918 [1759], 3). Although this sentence is uttered by Pangloss, it is really written by Voltaire to put readers in mind of Leibnizian optimism, from which he dissociates himself. On the pretence theory, Voltaire must therefore pretend to be someone with a deficient viewpoint. Clearly, as the author of Candide, Voltaire does not pretend to be Pangloss, or indeed any other character in the fiction. He also cannot pretend to be someone outside the fiction who asserts these viewpoints, because it is Pangloss who does the asserting in the fiction.

Nevertheless, Voltaire could pretend to be an author who endorses the deficient thoughts asserted by Pangloss, or at least fails to see their deficiency. This option involves what Currie calls a "second author", whereby an author makes it "fictional that someone other than herself is the author of [a] fictional story" (2010, 70-71). However, this solution inadequately captures the successful uptake of ironic characters, which involves what Wayne Booth calls a "secret communion" between author and reader $(1983,300)$. Booth explains that "[i]n the irony with which we are concerned, the speaker [in a narrative fiction] is himself the butt of the ironic 
point. The author and reader are secretly in collusion, behind the speaker's back, agreeing upon the standard by which he is found wanting" (1983, 304). The second-author solution falters in the case of Candide, because Voltaire is really in a secret communion with audiences behind the back of Pangloss (who asserts the deficient viewpoints), not behind the back of some imaginary author (who endorses them).

By contrast, whereas the pretence theory fails to explain the successful uptake of ironic characters, the echoic theory can easily explain why Voltaire's communication is ironic. Voltaire echoes Leibniz's thoughts by creating a fiction in which Pangloss endorses thoughts that are similar in content to Leibniz's. Voltaire's communicative act is tacit because it remains implicit that he really attributes Pangloss's thoughts to Leibniz. Moreover, Voltaire also does not explicitly state that he really dissociates himself from those thoughts. The audience are left to infer the real meaning of Voltaire's utterance. For this reason, an undiscerning reader or someone unfamiliar with Leibniz's optimism might miss the irony altogether. These characteristics of ironic characters are prototypical of communicative irony and can easily be explained by the echoic theory.

Ironic characters testify to irony's complexity and its meritorious contributions to a philosophical project like Voltaire's critique of Leibnizian optimism. The philosophical legitimacy of Candide proves that the dissociative stancetaking of irony is not by default detached dissimulation. In this respect, it is particularly puzzling that Lear ascribes the prevalence of moral suspicion to "the tendency in the culture to treat irony as satire" (2011, 119). Clearly, satire like Voltaire's Candide is hardly a pinnacle of detachment and whimsy. Moreover, the use of ironic characters in satire, as dissociation from absurd ideals, can serve as a uniquely valuable response to disruption in our moral lives. To understand why, we must consider how the disruption of moral imperfection sometimes prevents us from achieving human excellence.

\section{Ironic Characters and Moral Imperfection}

It is not merely the case that Lear's uncanny disruption is a peripheral form of irony; I also doubt that it (always) orients us toward human excellence. Concretely, there are occasions of disruption when erotic uncanniness cannot orient us toward excellence in our practical identity because it would clash with achieving excellence in another practical identity. Such disruption, which follows from value incompatibility, is unavoidable in our moral lives and can cause mental suffering. To sustain mental wellbeing, we need to accept our limits in achieving human excellence, i.e. our moral imperfection. Ironic characters can play a virtuous role in this process by offering us emotional distance which soothes mental suffering. Specifically, the dissociative stancetaking inherent in ironic characters can be put to virtuous use in negotiating a mean between too much disruption (a complete breakdown of practical deliberation in face of one's imperfection) and too little disruption (complete insensitivity toward one's imperfection).

The disruption of value incompatibility arises when the values embedded in multiple practical identities clash. Valerie Tiberius explains that "[i]f my conception of how to live requires doing everything I can to prevent extreme suffering and paying special attention to my friends and family, then I will never be in a position to reflect on my life and assess that I am meeting all of my own standards, or even coming close to it" $(2008,179)$. In other words, I may experience disruption because my values and obligations as a parent clash with my 
commitments as a volunteer. Such value incompatibility causes the kind of disruption described by Lear, because we experience our attempts as so woefully inadequate that we are unsure what it would even mean to be both a 'parent' and 'volunteer'.

Pace Lear, such disruption does not inherently reorient us toward excellence, because being excellent as a parent is to some extent incompatible with being excellent as a volunteer. Sure, we can be a parent and a volunteer. However, we do not have the resources to be both the best 'parent' and best 'volunteer' we can be (especially if also try to be the best 'friend', 'colleague', or 'pianist' we can be). There is no immediate solution to this problem. We must therefore learn to "live with the conflict, recognizing that one's conception of a good life [including harmony between one's values] cannot be fully realized in the world as it unfortunately happens to be" (Tiberius 2008, 179). Yet, living such a life is easier said than done, which is why we need to find a "strategy for coping with an imperfect world" (Tiberius 2008, 180).

Ironic characters in satire can serve as exactly such a strategy for coping with the disruption of value incompatibility, specifically to distance ourselves from an otherwise destructive ideal of moral perfectionism. Consider a cartoon by Andy Singer $(2004,123)$, in which he not only uses ironic characters to ridicule the absurdly defective viewpoints of a self-made businesswoman, arms dealer, and army general, but equally to mock a fictional satirist who is convinced that he is emancipating the world (Fig. 1).

\section{NO EXIT}

(C) Andy Singer

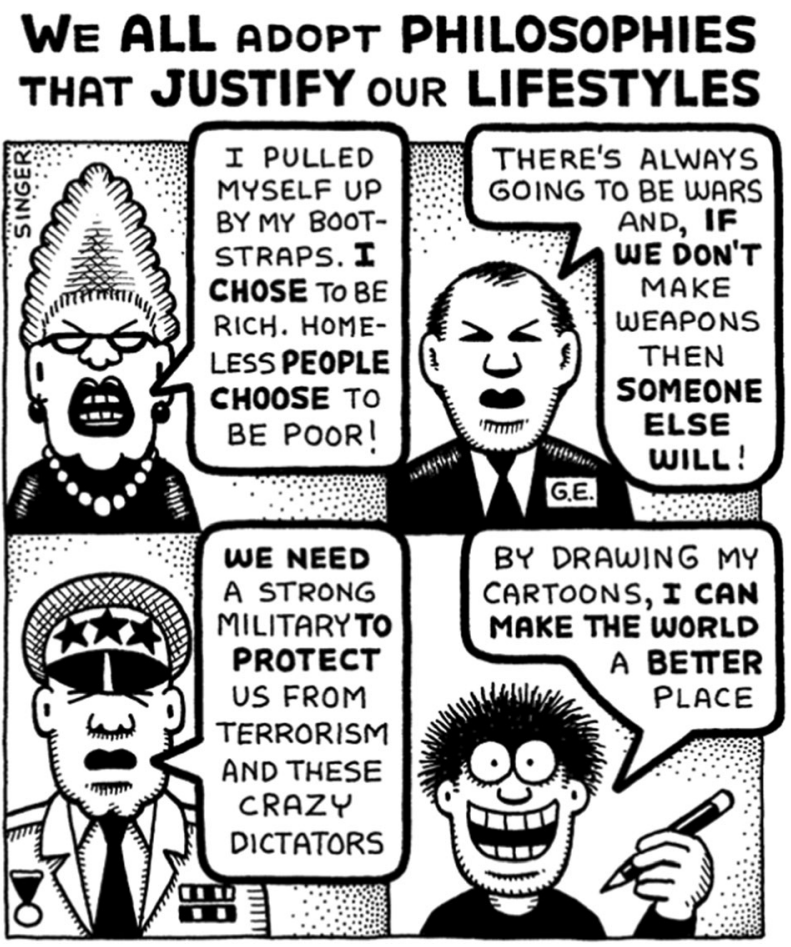

Fig. 1 We all adopt philosophies that justify our lifestyles 
The fictional satirist is clearly a stand-in for Singer himself - or, more precisely, the part of his personality that is prone to pursue an unattainable moral ideal. Aspiring to this unattainable moral ideal is unhealthy, as is clear from signifiers of mental ill health, like the wild hair, blank stare, and inane grin.

Singer's self-irony serves to address a disruption acknowledged by many satirists. Fellow cartoonist Dan Perkins (aka Tom Tomorrow) acknowledges that "[y]ou have to want to save the world in order to get up every day and do this work [satire], but in order to maintain your sanity, you simultaneously have to understand that you're just not going to" (Rall 2002, 28). Perkins's remark exhibits a kind of irony which resembles Lear's uncanny disruption. In this respect, 'satirist' is a practical identity which is defined by the aspiration to expose social wrongness with an eye to its termination. Yet, there is no conceivable way of creating satire that could ever fully live up to that aspiration, which causes disruption. For what is a 'satirist', if not someone fully committed to change the world?

Pace Lear, this disruption does not orient the reflexive satirist toward achieving excellence in a way which surpasses received understandings of being a 'satirist'. Rather, the point is exactly that the practical identity of the reflexive satirist is disrupted because they can never live up to the moral ideals that define that very identity. The disruption experienced by the reflexive satirist follows from an incompatibility between moral value (the care for others) and prudential value (the care of self). As Blackburn puts it, "[w]e simply cannot shoulder the burden of the entire world" $(1998,221)$, which is why "[w] need and cherish spheres within which we are completely absorbed by private concern and emotion" $(1998,22)$. The fictional satirist in Singer's cartoon is unable to make that concession and acknowledge his moral imperfection, which causes mental ill health.

Singer's fictional cartoonist no doubt suffers from 'neurotic perfectionism'. A neurotic perfectionist "compare[s] their values with inaccessible goals" (Geranmayepoura and Besharat 2010, 634). Therefore, neurotic perfections are never satisfied with their achievements and constantly feel guilty and shameful about "their alleged underachievements" (Stoeber et al. 2007, 131). In this respect, Blackburn acknowledges that moral deliberation has gone awry when it becomes "obsessive and neurotic" and when people are "destroyed by neurotic and obsessive misplaced guilt (...) and the feeling of having let themselves or others down, when no such feelings are appropriate" $(1998,16)$. It is exactly from such moral obsession and neuroticism that Singer dissociates himself through self-representation as an ironic character.

A similar process of ironic dissociation characterises the representation of Chidi Anagonye, a fictional ethics professor in the American comedy series The Good Place (2016-2019). Chidi finds himself in an afterlife that is loosely modelled on Christian eschatology. At the start, Chidi believes he has made it to the titular 'good place', because he always tried to make the morally perfect choice. Yet, Chidi's moral conscientiousness is also his tragic flaw because he is painfully aware of all the consequences of his decisions. As a result, Chidi's moral deliberation is so neurotic and obsessive that it becomes completely unsuccessful. Chidi can never reach a decision and, unable to identify the perfect moral action, he does not act at all (or incessantly postpones).

This complete breakdown of practical deliberation is Chidi's ultimate undoing. Failing to find the perfect bar for a drink with his best friend, Chidi remains frozen on the pavement for thirty minutes, until an air conditioner unit falls from a window and hits him straight on the head. Chidi's troubling experiences in the afterlife ultimately make him realize that he is in the 'bad place', where tormented souls experience psychological torture equivalent to their character flaws. In Chidi's case, what really makes the bad place so bad is that he constantly 
has to make decisions, which permanently gives him a stomach ache. In other words, because of his moral perfectionism, Chidi experiences mental suffering and a complete breakdown of practical deliberation.

What Chidi lacks to dissociate himself from his moral perfectionism is a sense of practical wisdom, which the makers of The Good Place do exhibit in their representation of him as an ironic character. According to James E. Birren and Lauren M. Fisher, "[w]isdom seems to emerge as a dialectic that, on one pole, is bounded by the transcendence of limitations and, on the other, by their acceptance" (1990, 324). Similarly, Positive Psychologists identify wisdom as a matter of the right "perspective" (Peterson and Seligman 2004, 181). This right perspective involves a degree of self-acceptance and acceptance of unchangeable circumstances, which are commonly advocated as strategies to prevent mental health issues like stress, anxiety, and depression (NHS Staff 2018a, 2018b). In this regard, wisdom as a character virtue correlates with the absence of neuroticism (Staudinger et al. 1997).

Ironic characters, like Chidi or Singer's fictional satirist, are a manifestation of such practical wisdom. Their representation involves a dissociative stancetaking from moral perfectionism, which frames it as absurdly defective. Concretely, through the ironic character of the fictional satirist, Singer comes to terms with his limitations in changing the world. In the absence of such a coping strategy, he is bound to damage his wellbeing and decision-making (as the example of Chidi shows). Hence, for Singer, ironic dissociation from his inner perfectionist creates just the right amount of distance from debilitating moral perfectionism to continue creating satire.

The idea that irony can appropriately distance us from unavoidable limitations is not entirely new. Pierre Hadot refers to Socratic irony as a coping strategy for epistemic imperfection, calling it "a kind of humor which refuses to take oneself or other people entirely serious" (2002, 25). Similarly, to deal with absurd uncertainty about whether our values matter, Thomas Nagel advises that "we return to our familiar convictions with a certain irony and resignation" (2012 [1979], 20). Likewise, Wilhelm Schmid argues that irony helps us deal with insoluble existential contrarieties by enabling us to reassess ourselves and our circumstances from an external viewpoint, which puts them in perspective (1998, 376). These ideas echo Lear's argument that irony can reorient us in response to disruption of practical identity. However, pace Lear, irony does not reorient us toward human excellence, but dissociates us from a debilitating ideal of human excellence, i.e. moral perfectionism.

At the same time, Schmid also identifies the "dangers" of too much dissociation, specifically "the habit of the subject to resign in unbearable contrarieties and only ironise them" and thus "never speak seriously anymore, show no spine, support nothing, so that everything goes" (1998, 380, my translation). This is the kind of irony that philosophers and cultural critics are worried about because it echoes moral commitment only to dismiss it as ridiculous. (Values? Yeah right.) Such irony typically constitutes an attempt to flippantly deflect disappointment in response to suffering that cannot be abated. It distances us from our moral imperfection altogether and makes us morally apathetic. Hence, what is required is a virtuous irony that strikes the right balance between too little disruption (complete insensitivity) and too much disruption (complete breakdown of practical deliberation).

Ironic characters in arts and media are uniquely valuable because they provide a clearly developed example of how we can cultivate such a virtuous irony. The aesthetic appreciation of ironic characters requires "narrative thinking", which involves understanding and appreciating "divergences" between perspectives, for example between perspectives of characters internal to the story, or between the internal perspective of a character and the external 
perspective of the author, etc. (Goldie 2012, 30). Specifically, to engage with an ironic character like Chidi, we must understand and appreciate that his perspective is defective and diverges from the reasonable perspective of The Good Place's writers. Crucially, we can adopt this process of narrative thinking and put it to virtuous use in our moral lives.

Specifically, we can learn to cope with the disruption of value incompatibility and moral imperfection by dissociating ourselves from a neurotically perfectionist version of ourselves. Doing so, we dissociate ourselves from moral perfectionism, by appreciating how defective we would be if we really were like Chidi or Singer's fictional satirist. This strategy builds on the ordinary role of narrative thinking in practical deliberation. Peter Goldie explains how we often think through our thoughts and actions from an external perspective to guide our reflection about the past and planning for the future (2004, 109-111). He explains how such narrative thinking about ourselves is characterised by an ironic gap; reflecting on the ignorant beliefs we held as a teenager, we now feel a certain amusement at the expense of our previous self, which guides us to make more enlightened choices in the future (Goldie 2012, 56).

Such narrative thinking about our previous self is identical to reorienting our practical deliberation by getting to see ourselves as 'such a Chidi' in situations where our moral ideals risk suffocating us. Goldie explains that fictional characters like Chidi often serve as a resource in our practical identity; we think of ourselves as "a loser like Marilyn Monroe's Sugar Kane in Some Like It Hot; a loner like the James Coburn character in The Magnificent Seven; a lover like Jack Nicholson in Carnal Knowledge (2004, 116). Similarly, Hilde Lindemann argues that "[p]ersonal identities consist of a connective tissue of narratives" and "many contain stock plots and character types that are borrowed from narratives that circulate widely in the culture" $(2001,72)$. Therefore, what makes ironic characters in popular media uniquely valuable is that we can adopt and adapt them in our narrative thinking to cope with the disruption of value incompatibility and moral imperfection.

\section{Conclusion}

According to Lear, irony functions as an Aristotelian virtue, holding a "mean between excess and defect" (2011,32). Similarly, I have argued that whereas too much irony leads to moral apathy, too little irony leads to moral neuroticism and mental ill health. Yet, I have challenged Lear's conception of irony as an experience of uncanny disruption which orients us toward human excellence. Not only is Lear's understanding of irony too idiosyncratic to alleviate common moral suspicions about irony, his account also overlooks the disruption of value incompatibility, which does not reorient us toward human excellence, but instead confronts us with our moral imperfection. Introducing ironic characters, I have outlined how a complex form of communicative irony can be put to virtuous use by helping us cope with the unavoidable disruption of imperfection in our moral lives.

My proposal attenuates common moral suspicions about irony in arts and media by showing how an ironic strategy can contribute to sustaining mental wellbeing and healthy practical deliberation in the face of disruptive value incompatibility. Moreover, formulating effective coping strategies in response to such disruption has never been more pressing. While value incompatibility is of all ages, it is intensified by increased knowledge about the consequences of our actions, which can cause clashes between values embedded in our different practical identities. In this respect, global information technology has made us often painfully aware that our aspirations to be the best possible 'friend', 'colleague', or 'pianist' can 
make us indirectly contribute to climate change or social injustice. We now have no way of not knowing about the cost of flying across the world to attend to our ill friend's needs or deliver that prestigious piano recital. To sustain good mental health and successful practical deliberation in this environment with increased opportunities for disruption, we need coping strategies like ironic characters more than ever.

Acknowledgements Thanks to Alfred Archer, Stacie Friend, Henk van Gils, Ami Harbin, Kristien Hens, Pilar Lopez-Cantero, Hans Maes, Constantin Mehmel, Christoph Menke, Lubomira Radoilska, Katrien Schaubroeck, Clint Verdonschot, and two anonymous referees for helpful feedback on earlier versions of this paper. Thanks also to David Brown, Gregory Currie, Manuel Garin, and James MacDowell for conversations about irony.

Open Access This article is licensed under a Creative Commons Attribution 4.0 International License, which permits use, sharing, adaptation, distribution and reproduction in any medium or format, as long as you give appropriate credit to the original author(s) and the source, provide a link to the Creative Commons licence, and indicate if changes were made. The images or other third party material in this article are included in the article's Creative Commons licence, unless indicated otherwise in a credit line to the material. If material is not included in the article's Creative Commons licence and your intended use is not permitted by statutory regulation or exceeds the permitted use, you will need to obtain permission directly from the copyright holder. To view a copy of this licence, visit http://creativecommons.org/licenses/by/4.0/.

\section{References}

Bernstein RJ (2016) Ironic life. Polity, Cambridge

Birren JE, Fisher LM (1990) The elements of wisdom: overview and integration. In: Sternberg RJ (ed) Wisdom: its nature, origins, and development. Cambridge University Press, New York, pp 317-332

Blackburn S (1998) Ruling passions. Oxford University Press, Oxford

Booth WC (1974) The rhetoric of irony, 2nd edn. University of Chicago Press, Chicago

Burgers C, van Mulken M, Schellens PJ (2011) Finding irony: an introduction of the verbal irony procedure (Vip). Metaphor \& Symbol 26(3):186-205

Currie G (2011) The irony in pictures. The British Journal of Aesthetics 51(2):149-167

Currie G (2006) Why irony is Pretence. In: Nichols S (ed) The architecture of the imagination: new essays on Pretence, possibility, and fiction. Clarendon Press, Oxford, pp 111-136

Fisher M, Taub A (2018) Should we all be taking 'irony poisoning' more seriously? New York Times, 23 August. https://static.nytimes.com/email-content/INT_4981.html

Wallace F, David (1993) E Unibus Pluram: television and U.S. fiction. Rev Contemp Fict 13(2):151-194

Frazier B (2006) Rorty and Kierkegaard on irony and moral commitment. Philosophical and Theological Connections. Houndmills: Palgrave Macmillan

Geranmayepoura S, Besharat MA (2010) Perfectionism and mental health. Procedia Social and Behavioral Sciences 5:643-647

Goldie P (2004) On personality. Routledge, London

Goldie P (2012) The mess inside. Narrative, emotion, and the mind. OUP, Oxford

Hadot P (2002) What is Ancient Philosophy? Translated by Michael chase. Harvard University Press, Cambridge

Hutcheon L (1985) A theory of parody: the teachings of twentieth-century art forms. Methuen, New York

Kierkegaard S (1841) 1989. The Concept of Irony, with Continual Reference to Socrates: Together with Notes of Schelling's Berlin lectures. Translated and edited by Howard V. Hong and Edna H. Hong. Princeton: Princeton University Press

Lear J (2011) A case for irony. Harvard UP, Cambridge, MA

Lindemann H (2001) Damaged identities, narrative repair. Cornell University Press, Ithica

Lippitt J (2000) Humour and irony in Kierkegaard's thought. Palgrave Macmillan, Houndmills

Mahdawi A (2017) Is Lena Dunham's 'hipster racism' just old-fashioned prejudice? The Guardian, 25

November. https:/www.theguardian.com/world/2017/nov/25/hipster-racism-lena-dunham-prejudice

Marwick A, Lewis R (2015) Media manipulation and disinformation online. Data Society, 24 November. https:// datasociety.net/pubs/oh/DataAndSociety_MediaManipulationAnd DisinformationOnline.pdf

Nagel, Thomas. (1979) 2012. Mortal Questions. Cambridge: Cambridge University Press 
Nehamas A (1998) The art of living: Socratic reflections from Plato to Foucault. University of California Press, Berkeley

NHS Staff 2018a. "Reduce stress." NHS. https://www.nhs.uk/conditions/stress-anxiety-depression/reduce-stress/

NHS Staff 2018b. "Feel better and happy." NHS. https://www.nhs.uk/conditions/stress-anxiety-depression/feelbetter-and-happy/

Peterson C, Seligman MEP (2004) Character strengths and virtues: a handbook and classification. Oxford University Press, New York

Popa-Wyatt M (2014) Pretence and Echo: Towards an Integrated Account of Verbal Irony. International Review of Pragmatics 6:127-168

Rall T (ed) (2002) Attitude. The new subversive political cartoonists. NBM Publishing, New York

Rorty R (1989) Contingency, irony, and solidarity. Cambridge University Press, Cambridge

Rosenblatt R (2001) The age of irony comes to an end. Time, September 24. http://content.time. com/time/magazine/article/0,9171,1000893,00.html

Schmid W (1998) Philosophie der Lebenskunst: eine Grundlegung. Suhrkamp, Berlin

Sholl J (2011) Ironie, Unheimichkeit en ontwarring: een gesprek met Jonathan Lear. In Wijsgerig Gezelschap 5: $9-16$

Singer A. (2004) No exit, edited by Ted Rall. New York: NBM

Söderquist BK (2007). The isolated self. Truth and Untruth in Søren Kierkegaard's On The Concept of Irony. Chicago: University of Chicago Press

Sperber D, Wilson D (2012) Meaning and relevance. Cambridge University Press, Cambridge

Staudinger, Ursula M., David F. Lopez, and, Paul B. Baltes. 1997. "The psychometric location of wisdom-related performance: intelligence, personality, and more?" Personality and Social Psychological Bulletin 23: 12001214

Stoeber J, Harris RA, Moon PS (2007) Perfectionism and the experience of pride, shame, and guilt: comparing healthy perfectionists, unhealthy perfectionists, and non-perfectionists. Personal Individ Differ 43:131-141

The Good Place. 2016-2019. Created by Michael Schur. US: NBC

Tiberius V (2008) The reflective life: living wisely with our limits. Oxford University Press, Oxford

Vlastos G (1991) Socrates: ironist and moral philosopher. CUP, Cambridge

Voltaire. (1759) 1918. Candide. Translated by Philip Littell. New York: Boni and Liveright

Wampole, Christy. 2012. "How to live without irony." The New York Times, November 17. https://opinionator. blogs.nytimes.com/2012/11/17/how-to-live-without-irony/

Wampole, Christy. 2016. "How to live without irony (for real this time)." The New York Times, December 19. https://www.nytimes.com/2016/12/19/opinion/how-to-live-without-irony-for-real-this-time-.html

Williams B (2002) Truth and truthfulness. Princeton University Press, Princeton

Publisher's Note Springer Nature remains neutral with regard to jurisdictional claims in published maps and institutional affiliations. 